UDC 316.774:343.353:316.7

DOI https://doi.org/10.32838/2710-4656/2021.6-3/29

Synchak B. A.

Private Higher Educational Institution "Kyiv University of Culture"

\title{
OLIGARCHIZATION AND OFFSHORIZATION AS A PROBLEM TRANSPARENCIES OF THE UKRAINIAN MEDIA MARKET
}

The article characterizes the phenomena of oligarchization and offshorization as factors that are problematic conditions of influence on the domestic media market. A generalized analysis of Ukrainian media property, which belongs to oligarchs, is carried out. The sectors of influence of the most popular media holdings are characterized according to the results of the collected information. The problem of offshorization is associated with big business in Ukraine, and therefore a parallel is drawn to the direct impact of the situation on the mass media, which are owned by oligarchs. The study considers and analyzes an alternative model of information influence, which predetermines the importance of scholars'attention to media ownership and information management tools within a particular country. The oligarchic owners of Ukrainian TV channels, radio stations, Internet media, and accompanying information about them are identified, which helps to track the potential personal interest. Because ten of the top ten domestic TV channels are owned by oligarchs, the question of the acceptability of monopolization of the Ukrainian media market is raised. The article presents four categories for understanding the principle of offshore operations, this information is linked to the current realities of the Ukrainian media market and the derivative threats that offshore operations pose. The general picture of the results of the study is linked to the conditions and factors of influence on the domestic media market.

Key words: oligarchization, offshorization, Ukrainian media ownership, owners of Ukrainian media, journalistic ethics, transparency of the media market, media monopolization.

The issues of oligarchization and factorization are on the agenda in countries that strive to maintain a strong economy and a healthy civil society. An important place in covering and conveying the understanding of this issue to society is occupied by the media. However, the national information present is actively monopolized by oligarchs. In today's reality, Ukrainian media ownership is seen as an instrument of influence. This contradicts the journalist's original niche - to tell the truth. The study of acute angles of Ukrainian media ownership will help to streamline them, to establish and optimize the problematic factors existing within the mass media environment.

O. B. Volkov, A. I. Petrushka, V. V. Bradov, L. Zmey, I. A. Grin, and others have studied issues related to the oligarchization of the media market. The works of these scientists mainly characterize aspects of the pre-election functioning of the media, the dependence of the media on politicians, and the corrupt element in journalism. However, these authors did not engage in the generalization and analysis of this kind proposed in the article. That is why the study aims to illustrate the state of domestic media ownership by structuring its categories and spheres of influence. Based on the results obtained, to characterize the relationship of oligarchization and offshorization with the information present.

Main part. As far back as in Ancient Greece discussing how the country should function better in the field of politics, Plato in his dialogues called State identifies oligarchy as "a system in which everything depends on the property qualification, the power there is in the hands of the rich, and the poor do not take part in the government" [1]. However domestic oligarchic realities are closely intertwined with the democratic ones guaranteed by the Constitution. Given the opposition of these concepts, there is a legitimate question about the possibility of coexistence of this order of things. However, the nature of this situation is not unbelievable if we resort to the analysis of the key lever of influence on public opinion which is the mass media. Taking into account that "more than $75 \%$ of Ukrainians regularly watch television channels of Ukrainian oligarchs" [2], it is possible to conclude the coefficient of their influence on public consciousness. To illustrate the importance of information influence we consider the process of its functioning as a part of being. Figure 1 shows an alternative model of the influence of information on public consciousness. 


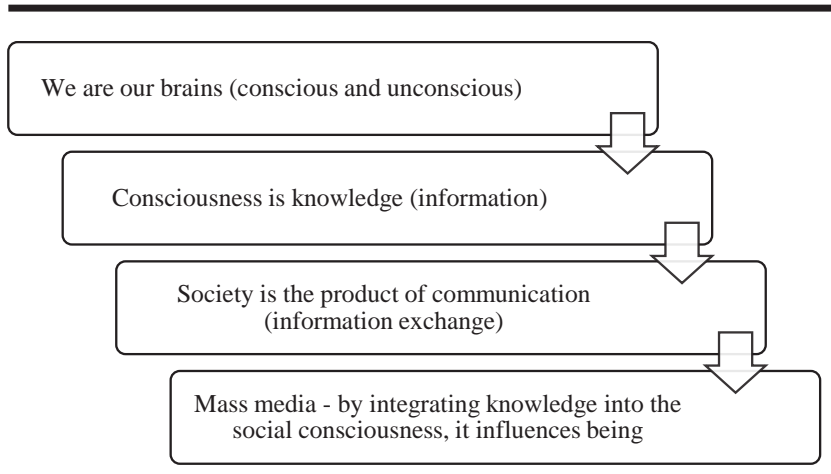

Fig. 1. Alternative model of informational influence

Proceeding from theunderstanding of the mentioned algorithm we come to conclusions in the form of a famous aphorism "who owns information owns the world". In our case who owns domestic media has leverage to influence local Ukrainian worldview. According to this, public opinion, or individual position depend on a range of information with which the mass or an individual is saturated. However, the efficiency of such influence depends on many factors, one of which is information consciousness. According to the results of recent researches by Media Detector, "the majority of Ukrainians never check messages for reliability, and the fourth part considers the problems of misinformation, jeans, and manipulations in media irrelevant" [3]. Thus, paraphrasing Plato in this context we consider the "property qualification" as the state of officials, but the varieties of "power" we divide into two categories: financial (business, including lobbying their interests in politics) and official (personal opportunities, including business). Although in Ukraine, these categories closely cooperate, this conditional division will help to conclude the target spheres of influence and priorities in the editorial policy of media owners in the future.

The Ukrainian oligarchy regularly enters the world lists of billionaires. According to a new ranking by Forbes magazine [4] and calculations by the National Security and Defense Council [5], Rinat Akhmetov, Petro Poroshenko, Dmitry Firtash, Igor Kolomoysky, Viktor Pinchuk, Sergei Lyovochkin, Viktor Medvedchuk, Vadim Novinsky, Yuri Kosyuk, Oleg Bakhmatyuk, Konstantin Zhevago, and the Greg spouses may fall under the oligarch criteria. Is it any wonder that eight (in italics) of the above list are owned by the media? Table 1 contains collected and structured information, which demonstrates the authorities' coverage of ownership rights among Ukrainian TV channels.

Starting from seven, eight, and ending with one or three popular TV channels are owned by different
Ukrainian oligarchs. This information is combined from the "Database of media and owners" on the specialized resource "Media ownership monitor Ukraine", which is supported by the Institute of Mass Information. This platform has data on the "risk indicators of media pluralism", the oligarchy, and "the ends of Ukrainian media ownership hidden in the offshore" [7]. Unfortunately, this database contains information with the current state as of 2017 , so to form an actual list of oligarchic owners of the Ukrainian media were attracted "detailed analysis" [6] from the Ukrainian literary newspaper 2021, and related information from the journalistic materials of "Media Detector" and "Ukrainska Pravda".

According to the latest publicized data from the National Television and Radio Broadcasting Council "among IPTV / OTT users in Q3 2019", the top $10 \mathrm{TV}$ channels include (see Figure 2): "1 + 1", "2 + 2", "TET" - Kolomoyskyi; "Ukraine" - Akhmetov; "ICTV", "STB", "Novyi" Pinchuk; and "Inter", "NTN", "K1" - Firtash [10]. Since all the TV channels mentioned above are owned by oligarchs, and the domestic media property in itself is unprofitable [11], we consider this situation as the accumulation of influence tools by the latter, which directly proportionally affects the transparency of the media market, in particular, "how the media industry controls its resources because the economic power and efficiency of the media sector depend on them" [10]. When we talk about efficiency, we mean its intended purpose - to provide the public with truthful and objective information that reflects reality.

Next among the popular media formats are radio stations. This broadcasting format, the most used among motorists and people whose daily activities are not accentuated mentally and allows for re-filtering of radio, podcasts, and other modes of audio broadcasting. Table 2 contains information about Ukrainian radio ownership.

Among the owners of private radio stations, we find almost the same names of officials, except for a few new ones: Karpiy, Derkach, Kurchenko, who are involved in positions in the Verkhovna Rada or associated with those who can probably lobby for common interests through their powers. Continuing the conclusions about the objectivity of information, the concentration of eight, six, or even four radio stations in different officials significantly affects the media market and carries its risks to ensure democracy.

The third category of broadcast formats that are examined in the study is the Internet media. However, the information placed in Table 3 about 
Table 1

Oligarchic owners of Ukrainian TV channels [6; 7]

\begin{tabular}{|c|c|c|c|}
\hline № & Name of media & Owner & Accompanying information \\
\hline \multicolumn{4}{|c|}{ 1+1 Media Holding } \\
\hline 1. & " $1+1 "$ & \multirow{7}{*}{$\begin{array}{l}\text { Igor Kolomoysky, } \\
\text { Igor Surkis }\end{array}$} & \multirow{7}{*}{$\begin{array}{l}\text { - The owner of a significant share in the holding is oligarch Igor } \\
\text { Kolomoysky. } \\
\text { - The owner of another share in the holding is oligarch Ihor } \\
\text { Surkis [6]. } \\
\text { - "During the } 2019 \text { elections" } 1+1 \text { "actively supported } \\
\text { candidate V. Zelensky." [6]. }\end{array}$} \\
\hline 2. & "2+2" & & \\
\hline 3. & "TET" & & \\
\hline 4. & "PlusPlus" & & \\
\hline 5. & "1+1 International" & & \\
\hline 6. & UNIAN TB & & \\
\hline 7. & "Bigudi" & & \\
\hline \multicolumn{4}{|c|}{ "StarLightMedia" Media Holding } \\
\hline 1. & "ICTV" & \multirow[t]{7}{*}{ Olena Pinchuk } & \multirow{7}{*}{$\begin{array}{l}\text { - The owner is the daughter of the former second president of } \\
\text { Ukraine Leonid Kuchma. } \\
\text { - Her husband is Victor Pinchuk, a famous businessman, and } \\
\text { philanthropist, billionaire [7]. }\end{array}$} \\
\hline 2. & "ICTV Ukraine" & & \\
\hline 3. & "STB" & & \\
\hline 4. & "Noviy Kanal" & & \\
\hline 5. & "Oce TB" & & \\
\hline 6. & "M1" & & \\
\hline 7. & "M2" & & \\
\hline \multicolumn{4}{|c|}{ Media Holding "Inter Media Group" } \\
\hline 1. & Inter & \multirow{8}{*}{$\begin{array}{l}\text { Valery Khoroshkovsky, } \\
\text { Dmitry Firtash }\end{array}$} & \multirow{8}{*}{$\begin{array}{l}\text { - Among the main owners are oligarch Dmytro Firtash } \\
\text { and Serhiy Lyovochkin, an MP and head of the presidential } \\
\text { administration under Viktor Yanukovych. } \\
\text { - During the } 2019 \text { elections, he supported OPZJ. } \\
\text { - Until 2015, almost one-third of the shares of the Inter TV } \\
\text { channel was owned by the Russian First Channel [6]. }\end{array}$} \\
\hline 2. & $\begin{array}{l}\text { "Kino-TB" (TV channel } \\
\text { "Inter-Film") }\end{array}$ & & \\
\hline 3. & $\begin{array}{l}\text { "Muzika-TB" ("Pixel” TV } \\
\text { channel) }\end{array}$ & & \\
\hline 4. & K1 & & \\
\hline 5. & K2 & & \\
\hline 6. & "Mega" & & \\
\hline 7. & NTN & & \\
\hline 8. & Zoom & & \\
\hline \multicolumn{4}{|c|}{ Media Holding “Media Group Ukraine” } \\
\hline 1. & "Ukraine" & \multirow[t]{7}{*}{ Rinat Akhmetov } & \multirow{7}{*}{$\begin{array}{l}\text { - The TV channel "Ukraine" has been repeatedly criticized by } \\
\text { the National Council for "inciting hatred" [6]. } \\
\text { - According to many offshore companies, it is owned by } \\
\text { oligarch Rinat Akhmetov [6]. } \\
\text { - Through the TV channel "Ukraine" the owner's reputation in } \\
\text { business is raised and his competitors are discredited. [6] }\end{array}$} \\
\hline 2. & "Ukraine 24" & & \\
\hline 3. & "NLO TV" & & \\
\hline 4. & "Indigo TV" & & \\
\hline 5. & "Football 1" & & \\
\hline 6. & "Football 2" & & \\
\hline 7. & "Football 3" & & \\
\hline \multicolumn{4}{|c|}{ Media Holding "News" } \\
\hline 1. & "112 Ukraine" & \multirow[t]{3}{*}{ Taras Kozak } & \multirow{3}{*}{$\begin{array}{l}\text { - The TV channels' live broadcasts have so far been blocked on } \\
\text { the owner's suspicion of “terrorism financing" [8]. } \\
\text { - The TV channels are associated with MP Viktor Medvedchuk } \\
\text { [8]. }\end{array}$} \\
\hline 2. & NewsOne & & \\
\hline 3. & ZIK & & \\
\hline 1. & "NASH" & Yevgeny Muraev & $\begin{array}{l}\text { - People's deputy of Ukraine of the VII and VIII convocations. } \\
\text { "Pro-Russian politician" [6]. }\end{array}$ \\
\hline & & & \\
\hline 1. & "Channel 5" & \multirow[t]{2}{*}{ Petro Poroshenko } & \multirow[t]{2}{*}{$\begin{array}{l}\text { - For "Pryamiy" reissued the license due to a change of owner - } \\
\text { the former president of Ukraine Petro Poroshenko [9]. }\end{array}$} \\
\hline 2. & "Pyramid" & & \\
\hline \multicolumn{4}{|c|}{ Television and Radio Company "Lux" } \\
\hline 1. & "Channel 24" & $\begin{array}{l}\text { Catherine Kit-Sadovaya, } \\
\text { Roman Andreyko, } \\
\text { Oksana Andreyko }\end{array}$ & $\begin{array}{l}\text { - The main owner is the wife of Andriy Sadovy, the mayor of } \\
\text { Lviv. } \\
\text { - Roman is a close friend of Andriy Sadovy [7]. } \\
\text { - He is married to Oksana Andreyko, who together with him is } \\
\text { co-owner of Radio } 24 \text {. }\end{array}$ \\
\hline 1. & "Espreso TV" & $\begin{array}{l}\text { Ivan Zhevago, } \\
\text { Larisa Knyazhitskaya }\end{array}$ & $\begin{array}{l}\text { - Ivan, the son of oligarch K. Zhevago, is the owner of } 75 \% \text { of } \\
\text { Espresso TV. } \\
\text { - Another } 22.5 \% \text { belongs to the wife of European Solidarity MP } \\
\text { M. Knyazhytskyy Larisa [7]. }\end{array}$ \\
\hline
\end{tabular}


Oligarchic owners of Ukrainian radio stations [6; 7]

Table 2

\begin{tabular}{|c|c|c|c|}
\hline № & Name of media & Owner & $\begin{array}{r}\text { Accompanying information } \\
\end{array}$ \\
\hline \multicolumn{4}{|r|}{ “TAVR Media” Radio Holding } \\
\hline 1. & "HITFM" & \multirow[t]{9}{*}{ Victor Pinchuk } & \multirow{9}{*}{$\begin{array}{l}\text { "From the very convoluted ownership structures of the stations, which were } \\
\text { once made public by Media Detector, one can understand that the holding is } \\
\text { connected with the family of the son-in-law of the second president Kuchma, } \\
\text { the oligarch Viktor Pinchuk" }[6 ; 12] \text {. }\end{array}$} \\
\hline 2. & "Melody FM" & & \\
\hline 3. & "Relax" & & \\
\hline 4. & "Radio Jazz" & & \\
\hline 5. & "Radio Rocks" & & \\
\hline 6. & "KISS FM" & & \\
\hline \multirow[t]{2}{*}{7.} & "Russian Radio & & \\
\hline & Ukraine" & & \\
\hline 8. & "Nashe Radio" & & \\
\hline \multicolumn{4}{|r|}{ Radio Holding “UMH” } \\
\hline 1. & "Retro FM" & \multirow[t]{10}{*}{ Sergey Kurchenko } & - "The holding was founded in the late 1990s by entrepreneur Borys \\
\hline 2. & "Autoradio" & & Lozhkin, who during the presidency of Petro Poroshenko was the head of \\
\hline 3. & "Jam FM" & & the Presidential Administration. However, later, in 2013, the media asset \\
\hline 4. & "Radio P'yatnitsa" & & was hought by an olioarch from President Yanukoyych's entourage Serhiv \\
\hline 5. & "NRJ" & & was bought by an oligarch from President Yanukovych's entourage Serhiy \\
\hline 6. & "Lounge FM" & & Kurchenko" [6]. \\
\hline & & & - "In 2017, the National Council for Television and Radio Broadcasting did \\
\hline & & & not renew 36 licenses of the holding's radio stations, and since September \\
\hline & & & 11, 2020, UMH media assets were transferred to the management of Igor \\
\hline & & & Kolomoysky’s 1+1 Media" [6]. \\
\hline \multicolumn{4}{|c|}{ Television and Radio Company "Lux" } \\
\hline 1. & "Maximum" & \multirow{4}{*}{$\begin{array}{l}\text { Catherine Kit- } \\
\text { Sadova, } \\
\text { Roman Andreyko, } \\
\text { Oksana Andreyko }\end{array}$} & \multirow{4}{*}{$\begin{array}{l}\text { "Roman is a close friend of Andriy Sadovy, the mayor of Lviv and the founder } \\
\text { of the broadcasting company Lux, as they studied together in Lviv. He is } \\
\text { married to Oksana Andreyko, who together with him is the co-owner of Radio } \\
24 \text { " [6]. }\end{array}$} \\
\hline 2. & "Nostalgie" & & \\
\hline 3. & "Lux FM" & & \\
\hline 4. & "Radio 24" & & \\
\hline \multicolumn{4}{|c|}{ "Radio Era" Television and Radio Company LLC } \\
\hline 1. & Radio ERA & Andrey Derkach & $\begin{array}{l}\text { "People's deputy of Ukraine of the eighth convocation. Honorary president } \\
\text { of media holding Era-media, chairman of the artistic council of TRK Era. } \\
\text { According to Novoye Vremya, he graduated from the Dzerzhinsky KGB } \\
\text { school in Moscow" [7]. }\end{array}$ \\
\hline \multicolumn{4}{|r|}{ I Ukrainian Radio Group } \\
\hline 1. & "Pepper FM" & \multirow[t]{3}{*}{ Andrey Karpiy } & \multirow{3}{*}{$\begin{array}{l}\text { "In } 2008 \text { I was a partner of Andriy Sadovy mayor of Lviv in PrAT "Radio } \\
\text { Lux". }\end{array}$} \\
\hline 2. & MFM & & \\
\hline 3. & Best FM & & \\
\hline
\end{tabular}

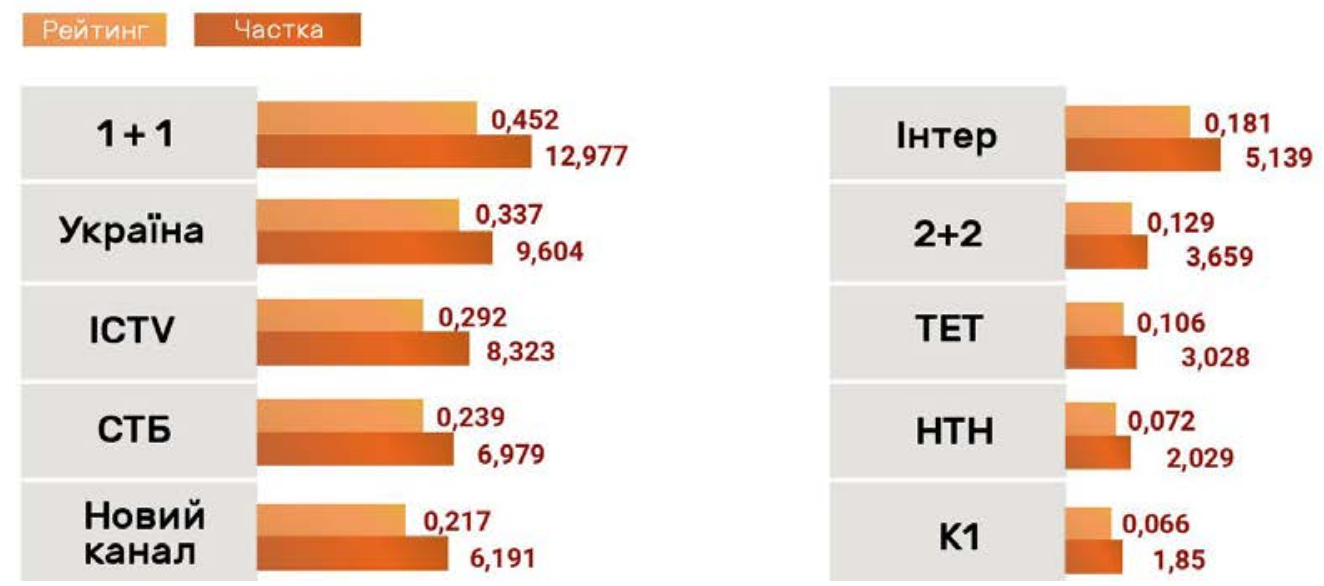

Fig. 2: Top 10 TV Channels by Rating [10] 
the oligarchic owners of such media is not exhaustive in characterizing the spheres of influence of officials on the Internet so there are various "illegal" ways to support a particular wave of information in social networks or on sites of different strains.

For example, Investigations.info's "I'm-bot" investigates how the bot industry works from the inside, who uses such services, and how much it costs. A journalist who took such a job undercover was tasked with writing 200-300 different comments daily under various fake accounts to support or discredit this or that political figure. There were dozens of them in the agency and they worked in three shifts and on different politicians. During one month of undercover journalism, "more than 40,000 comments were written on behalf of various politicians" [13]. Besides, there are varieties of advertisements and other paid options to raise a certain information wave on the Internet. In the aggregate, in addition to licensed Internet media, various tools of influence are used to lobby their interests and impose certain thoughts on the public, which increases its effectiveness.

Oligarchization is a problem for the media market because ownership of media outlets in such amounts (see Tables 1-3) can pose "threats to national security due to the excessive influence of persons with significant economic or political weight in public life". This is the definition of the new Oligarchs Bill. Which was previously announced by the President of Ukraine Volodymyr Zelensky, to "weaken the influence of oligarchs on the media". [14]. In case this draft law is adopted, the indicated mass media reality may change considerably. However, so far we have come to exactly these conclusions.

The topic of offshorization is worth an interpretative excursion because the interpretation of this concept depends on its relation to the topic of the study. In Tables 1-3 we have already mentioned related information about some of the offshore operations that directly affect the transparency of the media market.

Oligarchic Owners of Ukrainian Internet Media [6; 7]

Table 3

\begin{tabular}{|c|c|c|c|}
\hline № & Name of media & Owner & Accompanying information \\
\hline \multicolumn{4}{|c|}{ “1+1 Media" Holding } \\
\hline 1. & "TSN.UA" & \multirow[t]{3}{*}{ Igor Kolomoisky } & \multirow{3}{*}{$\begin{array}{l}\text { The owner of the news resources and the news agency UNIAN is } \\
\text { oligarch Igor Kolomoysky. }\end{array}$} \\
\hline 2. & "UNIAN" & & \\
\hline 3. & "Glavred.info" & & \\
\hline \multicolumn{4}{|c|}{ Media Holding "Ligamedia" } \\
\hline 1. & "Liga.NET" & Dmitry Bondarenko & $\begin{array}{l}\text { "The CEO of Ligamedia is a businessman and a member of the } \\
\text { Kyiv City Council of the VII convocation." [6]. }\end{array}$ \\
\hline 1. & "Obozrevatel" & Svetlana Brodskaya & $\begin{array}{l}\text { - Svetlana is the wife of the politician and third deputy Mikhail } \\
\text { Brodsky. } \\
\text { "Because of her friendly relationship with Brodsky, the } \\
\text { influence on the site is often attributed to the former chairman of } \\
\text { the Supreme Soviet and secretary of the National Security and } \\
\text { Defense Council, Alexander Turchinov" [6]. }\end{array}$ \\
\hline \multicolumn{4}{|c|}{ Television and Radio Company "Lux" } \\
\hline 1. & Website 24.tv & $\begin{array}{l}\text { Catherine Kit-Sadova, } \\
\text { Roman Andreyko, } \\
\text { Oksana Andreyko }\end{array}$ & $\begin{array}{l}\text { - The main owner is the wife of Andriy Sadovy, the mayor of } \\
\text { Lviv. } \\
\text {-"Roman is a close friend of Andriy Sadovoy". } \\
\text { - "Married to Oksana Andreyko, who together with him is the } \\
\text { co-owner of Radio 24" [6]. }\end{array}$ \\
\hline \multicolumn{4}{|c|}{ “Vesti-Ukraine" Media Holding } \\
\hline 1. & "Vesti" & Tatiana Alexandrova & $\begin{array}{l}\text { - "Vesti" was first associated with Victor Medvedchuk and Serhiy } \\
\text { Kurchenko [6]. } \\
\text {-"The current owner is a front person, to whom, among other } \\
\text { things, several fictitious firms related to the media holding Vesti- } \\
\text { Ukraine are registered. The holding includes newspaper "Vesti", }\end{array}$ \\
\hline 2. & ubr.ua & & $\begin{array}{l}\text { TV channel UBR, radio "Vesti", website vesti-ukr.com, website } \\
\text { reporter.vesti-ukr.com, website ubr.ua" [7]. }\end{array}$ \\
\hline \multicolumn{4}{|c|}{ Media holding company "Media-Invest Group" } \\
\hline 1. & "Today" & Rinat Akhmetov & \multirow{2}{*}{$\begin{array}{l}\text { - "Media Holding "Media-Invest Group" of the civilian wife of } \\
\text { former Minister of Revenue and Levies of Ukraine Oleksandr } \\
\text { Klymenko Olga Semchenko" [6]. }\end{array}$} \\
\hline 2. & "Strana.ua" & Igor Guzhva & \\
\hline \multicolumn{4}{|c|}{ “Focus Media" LLP } \\
\hline 1. & "Focus" Magazine & Boris Kaufman & $\begin{array}{l}\text { "The owner is a Ukrainian millionaire, businessman, former } \\
\text { deputy of the Odesa City Council" [7]. }\end{array}$ \\
\hline 1. & "Podrobnisti" & Dmitry Firtash & The resource is associated with oligarch Dmitry Firtash [7]. \\
\hline
\end{tabular}


For example, "due to many offshore companies, the TV channel "Ukraine" is owned by oligarch Rinat Akhmetov". "From the very convoluted ownership structures of radio stations, one can understand that the radio holding "TAVR Media" is connected with the family of the son-in-law of the second president Kuchma, oligarch - Viktor Pinchuk". The current owner of "Vesti" is a front person, to whom several fictitious firms related to the media holding "Vesti-Ukraine" are registered, among other things. To understand what is meant by these theses, it is necessary to divide the interpretation of offshorization into several substantive categories (see Table 4).

So for the domestic reality, the phenomenon of offshorization is a weighty factor that hinders the process of economic development of the country as a result of total non-payment of taxes and shadow business in offshore zones. "Ukraine is in the top ten leading countries in terms of export of capital. Part of these "withdrawn" funds is constantly returned by loans, investments, and corrupt payments" [17]. Thus, one can earn almost three times the same money. According to the Ukrainian Agency for Financial Development, about 90 percent of Ukrainian capital was moved to Cyprus in different years" [17]. It is logical to assume that this is the way most often used by those in whose hands big business is concentrated in Ukraine.

Conclusions. Among the most popular domestic TV channels, ten out of ten are owned by oligarchs.
The situation with radio and Internet media property is not too good. This state of affairs is characterized by the oligarchs' accumulation of instruments of influence. This affects the transparency elements of the media market, especially how the industry realizes its information potential because of its fundamental purpose - to provide the public with truthful and objective information. Some ownership structures are difficult to access because they pass through many offshore organizations and are sometimes registered in the name of fictitious persons. Apart from the direct influence on the transparency of the Ukrainian media market, general forshorization often implies shadow business and tax evasion. This situation is a significant problem for the national economy, and given the sphere of functioning (business of officials), it also concerns media ownership, at least as far as the editorial policy of private editions is concerned. Redistribution of the ownership structures of the Ukrainian media market is predicted with the signing of the draft law on prevention of threats to national security-related to excessive influence (particularly in the media) of persons with significant economic or political weight in public life (oligarchs). However, this topic requires new and relevant research. A situation in which " $75 \%$ of Ukrainians regularly watch the TV channels of Ukrainian oligarchs" and "most of them never check media reports for accuracy" is not acceptable for any healthy democratically oriented constitutional order.

Table 4

Four Categories for Understanding Offshoring [15; 16]

\begin{tabular}{|c|c|c|}
\hline \multicolumn{3}{|c|}{ № / category / explanations } \\
\hline \multicolumn{3}{|c|}{ 1. Global scale of the phenomenon } \\
\hline \multicolumn{3}{|c|}{$\begin{array}{l}\text { - "About } 85 \% \text { of international banking and bond issuance takes place offshore." } \\
\text { - "The U.S. Government Accountability Office reported in } 2008 \text { that } 83 \text { of the top } 100 \text { U.S. corporations have assets offshore." } \\
\text { - "Tax Justice Network experts found that } 99 \text { of Europe's top } 100 \text { companies used offshore" [15]. }\end{array}$} \\
\hline \multicolumn{3}{|c|}{ 2. The main offshore networks } \\
\hline \multicolumn{3}{|c|}{$\begin{array}{l}\text { - "Offshore mostly appears in small countries or islands. Low taxes and minimal legal requirements are the main way to make } \\
\text { money. Here they are divided into European "near-British" and American" [15]. }\end{array}$} \\
\hline European & “near-British" & American \\
\hline $\begin{array}{l}\text { Switzerland, Luxembourg, } \\
\text { Liechtenstein, Monaco, Andorra, } \\
\text { Cyprus }\end{array}$ & $\begin{array}{l}\text { Jersey, Guernsey, Isle of Man, and such islands } \\
\text { as the Cayman Islands British Virgin Islands, } \\
\text { Bermuda, Gibraltar }\end{array}$ & $\begin{array}{l}\text { American Virgin Islands, Marshall } \\
\text { Islands, Panama. }\end{array}$ \\
\hline \multicolumn{3}{|c|}{ 3. Peculiarities of offshore operations } \\
\hline \multicolumn{3}{|c|}{$\begin{array}{l}\text { - "Offshore zones have more favorable legislation than in the country of the businessman, thus it is possible to avoid paying a } \\
\text { significant amount of taxes"; } \\
\text { - "Offshore zones are places of mass registration of enterprises". In the British Virgin Islands, there are } 25000 \text { inhabitants but since } \\
1984800000 \text { companies were registered. The Cayman Islands have } 40000 \text { inhabitants, but } 65000 \text { companies were registered [16]; } \\
\text { - Offshore companies often operate on principles of secrecy, so it is difficult to identify the owner of companies in countries that do } \\
\text { not have international agreements with them. } \\
\text { - "International business is often divided into many companies that are registered in different jurisdictions, and therefore different } \\
\text { laws can be applied to the - more convenient for business in certain situations" [16]. }\end{array}$} \\
\hline \multicolumn{3}{|c|}{ 4. Motivation of the Western and Post-Soviet World } \\
\hline
\end{tabular}




\section{References:}

1. Платон. Держава / пер. $з$ давньогр. Д. Коваль. Київ : Основи, 2000. 355 с.

2. Rybak V. es, Ukraine's Oligarchs Own the Airwaves, but Their Days Are Numbered. Atlantic Council. 2018. URL: https://www.atlanticcouncil.org/blogs/ukrainealert/yes-ukraine-s-oligarchs-own-the-airwaves-buthere-s-why-their-days-are-numbered/ (дата звернення: 18.06.2021).

3. Індекс медіаграмотності українців (дослідження). Детектор медіa. 2021. URL: https://detector. media/community/article/186435/2021-03-29-indeks-mediagramotnosti-ukraintsiv-doslidzhennya/ (дата звернення: 18.06.2021)

4. Новий рейтинг українських мільярдерів від Forbes: майже всі олігархи збагатіли менш ніж за рік. Радіо Свобода. 2021. URL: https://www.radiosvoboda.org/a/forbes-rejtynh-miljarderiv-ukrajiny/31150398.html (дата звернення: 18.06.2021)

5. Романенко В. РНБО нарахувала 13 олігархів в Україні. Українська правда. 2021. URL: https://www. pravda.com.ua/news/2021/05/11/7293080/ (дата звернення: 18.06.2021)

6. Погуляєвський М. Кому належать українські ЗМІ: докладний аналіз. Украӥнська літературна газета. 2021. URL: https://itgazeta.com.ua/news/komu-nalezhat-ukrainski-zmi-dokladnyj-analiz/ (дата звернення: 18.06.2021)

7. Бази даних медіа та власників. Media ownership monitor Україна. 2017. URL: http://ukraine.mom-rsf. org/ua/vlasniki/individual-owners/ (дата звернення: 18.06.2021)

8. Зеленський заблокував канали Медведчука: РНБО наклала санкції. Українська правда. 2021. URL: https://www.pravda.com.ua/news/2021/02/2/7282097/ (дата звернення: 18.06.2021)

9. «Прямий» переоформив ліцензію у зв’язку з офіційною купівлею каналу Порошенком. Детектор медіа. 2021. URL: https://detector.media/rinok/article/188480/2021-05-27-pryamyy-pereoformyv-litsenziyu-uzvyazku-z-ofitsiynoyu-kupivleyu-kanalu-poroshenkom/ (дата звернення: 18.06.2021)

10. Рейтинги телеканалів серед користувачів IPTV/OTT у III кварталі 2019 року. Національна рада з питань телебачення та радіомовлення. 2020. URL: https://www.nrada.gov.ua/rejtyngy-telekanaliv-seredkorystuvachiv-iptv-ott-u-iii-kvartali-2019-roku/ (дата звернення: 18.06.2021)

11. Сокуренко Л. Медіавласність по-українськи: бізнес чи інструмент впливу? The Ukrainians. 2016. URL: https://theukrainians.org/vlasnist-media/. (дата звернення: 18.06.2021)

12. Кому належать українські радіостанції: від «ТАВР Медіа» до «Громадського радіо». Детектор медіa. 2016. URL: https://detector.media/infospace/article/114187/2016-04-08-komu-nalezhat-ukrainskiradiostantsii-vid-tavr-media-do-gromadskogo-radio/ (дата звернення: 18.06.2021)

13. «Я-бот». Ботоіндустрія зсередини: хто користується та скільки коштує. Слідство.Інфо. 2019. URL: https:/hromadske.ua/posts/ya-bot-film-rozsliduvannya-pro-te-yak-pracyuyut-ukrayinski-botofermi-ta-htoz-politikiv-koristuyetsya-yihnimi-poslugami (дата звернення: 18.06.2021)

14. Зеленський вніс до парламенту законопроєкт про олігархів. Детектор медіa. 2021. URL: https://detector.media/infospace/article/188728/2021-06-02-zelenskyy-vnis-do-parlamentu-zakonoproiekt-prooligarkhiv/ (дата звернення: 18.06.2021)

15. Шэксон Н. Люди обокравшие мир. Правда и вымысел о современных оффшорных зонах. Москва : «Коммерсантъ» ЭКСМО, 2012. 382 с.

16. Срмоленко В. Офшори у світі: 7 ключів для розуміння. Громадське. 2016. URL: https://hromadske.ua/posts/ofshory-u-sviti-7-kliuchiv-dlia-rozuminnia (дата звернення: 18.06.2021).

17. Костюк Б. «Офшоризація» української економіки. Що робити? Радіо Свобода. 2021. URL: https://www.radiosvoboda.org/a/27667157.html (дата звернення: 18.06.2021).

\section{СИНЧаК Б. А. ОЛІГАРХІЗАЦІЯ Й ОФШОРИЗАЦІЯ ЯК ПРОБЛЕМА ПРОЗОРОСТІ УКРАЇНСЬКОГО МЕДІАРИНКУ}

У статті характеризуються явищза олігархізащії й офшоризащії як чинники, щуо є проблемними умовами впливу на вітчизняний медіаринок. Проводиться узагальнений аналіз української медіавласності, яка належить олігархам. За результатами збірної інформації характеризуються сектори впливу найпопулярніших медіахолдингів. Проблема офиоризачії пов'язується з великим бізнесом в Україні, а отже, проводиться паралель на безпосередній вплив ситуачії на мас-медіа, які перебувають у власності олігархів. У дослідженні розглядається й аналізується альтернативна модель інформаційного впливу, котра зумовлюе важливість уваги науковців до медіавласності та інструментів керування інформацією в межах окремої краӥни. Ідентифікуються олігархічні власники украӥнських телеканалів, радіостаниій, інтернет-3МІ та супровідна інформація про них, щзо допомагає відстежувати потенційний персональний інтерес. 3 огляду на те, щуо десятьма з десяти топових вітчизняних телеканалів володіють олігархи, підіймається питання щзодо прийнятності монополізації українського медіаринку. У статті подаються чотири категорії для розуміння принципу дії офшорів, ия інформація пов 'язується з актуальними реаліями украӥнського медіаринку та похідними загрозами, які несуть у собі офшорні операщіі. Загальна картина результатів дослідження пов 'язується з умовами та факторами впливу на вітчизняний медіаринок.

Ключові слова: олігархізачія, офшоризація, українська медіавласність, власники украӥнських медіа, журналістська етика, прозорість медіаринку, монополізація мас-медіа. 